\title{
Syltodinium listii gen. et spec. nov., a marine ectoparasitic dinoflagellate on eggs of copepods and rotifers*
}

\author{
Gerhard Drebes \\ Biologische Anstalt Helgoland (Litoralstation); D-2282 List/Sylt, Federal Republic of \\ Germany
}

\begin{abstract}
Syltodinium listii is described as a new marine ectoparasitic dinoflagellate. In culture experiments the species was found feeding on eggs of planktonic copepods and rotifers. The dinospore penetrates the host by a peduncle, and transforms into a trophont by sucking out the egg contents phagotrophically. After detaching from the host, the mature trophont settles down to become a palmelloid multiplication stage. By repeated binary fission, up to 16 or 32 gymnodinoid, colourless dinospores are formed inside a gelatinous envelope. The parasite retains its dinoflagellate (monadoid) nature throughout its whole vegetative life cycle. Even during the trophic and multiplication phase the species remains latently motile. Despite some resemblance to Dissodinium, there are sufficient reasons for the establishment of the new genus Syltodinium.
\end{abstract}

\section{INTRODUCTION}

Ectoparasitic dinoflagellates on eggs of crustaceans were first described by Dogiel (1906). His three new species were transferred by Chatton (1912) to a new genus, Chytriodinium, later reinvestigated by Cachon \& Cachon (1968). Dissodinium Klebs in Pascher includes two species parasitizing eggs of planktonic copepods (Gönnert, 1936; Drebes, 1969, 1978). D. pseudocalani (Gönnert) Drebes ex Elbr. \& Dreb. was found feeding on eggs of only Pseudocalanus elongatus Boeck, whereas D. pseudolunula (Swift) ex Elbr. \& Dreb. prefers eggs of Temora longicornis Müller and Acartia sp., and even of the rotifer Synchaete sp. (Drebes, 1984). D. pseudolunula could be maintained continuously in culture, so far as host substrate was available, but until now only the vegetative life cycle was obtained under laboratory conditions. In addition, in plankton catches from the North Sea, stages were met with which were interpreted as resting cysts of the parasite (Drebes, 1981; John \& Reid, 1983).

Further attempts to get sexual reproduction of $D$. pseudolunula in culture failed, but led to a surprising result. After adding a high concentration of eggs of Temora and Acartia, freshly collected from the sea, into a Dissodinium culture, a few unknown life stages soon occurred. Since they could not be related to Dissodinium, they were separated and their further development followed. As a result, we were dealing with a new ectoparasitic dinoflagellate, only detected by chance as a contamination in a

- Dedicated to Dr. Dr. h. c. P. Kornmann on the occasion of his eightieth birthday 
Dissodinium culture. Once recognized, the new species described herein for the first time could be observed also in plankton samples taken from the Wadden Sea (German Bight). Though the cultures were prematurely lost and the observations thus still incomplete, the vegetative life cycle can be roughly outlined.

\section{MATERIALS AND METHODS}

First observed in August 1985 in a Dissodinium culture fed with copepod eggs, Syltodinium listii Drebes gen. et spec. nov. was later directly isolated from plankton samples taken from the Wadden Sea near List/Sylt (German Bight, North Sea). Clonal cultures of the parasite were established and maintained in Petri dishes in a nutrient enriched f/2 medium (McLachlan, 1973). Kept at a temperature of $15^{\circ} \mathrm{C}$ and an illumination of $14 \mathrm{~h}$ per day, $S$. listii was regularly supplied with the appropriate host substrate. Accordingly, once a week the parasite was fed with eggs of Temora longicornis, Acartia sp., or sometimes of Synchaete sp.

The vegetative life cycle was studied on living material at room temperatures using sea water immersion objectives (Leitz). For a raw analysis of the various cell structures, cytological methods common in light microscopy were applied.

\section{RESULTS}

Syltodinium Drebes gen. nov.

Ectoparasitic dinoflagellate on eggs of planktonic crustaceans and rotifers. Dinospores gymnodinoid. Food uptake phagotrophically by a peduncle. After feeding, the trophont detaches from the host and transforms into a palmelloid multiplication stage, embedded in a gelatinous envelope. Dinospores are formed by repeated binary fission. Type species: $S$. listii Drebes sp. nov.

Latin diagnosis: Dinoflagellata extoparasitica ad ova crustaceorum et rotatoriorum planctonicorum. Dinosporae gymnodinoideae. Receptio alimenti modo phagotrophico per pedunculum. Receptio alimenti finita trophontus separatus de hospite transformat in stadium palmelloideum multiplicationis involucro mucoideo circumdato. Dinosporae per bipartione repitita formantur. Typus generis: $S$. listii Drebes sp. nov.

\section{Syltodinium listii Drebes sp. nov.}

Ectoparasitic on eggs of marine copepods (Temora longicornis, Acartia sp., Pseudocalanus elongatus) and rotifers (Synchaete sp.). Dinospores colourless, 27-33 $\mu \mathrm{m}$ long, 22-27 $\mu \mathrm{m}$ wide. Epicone conical, hypocone hemispherical or conical. Girdle median, left-handed, sulcus extending from antapex to apex. Nucleus roundish oval,

Figs 1-4. Syltodinium listii. Fig. 1. A mature trophont having emptied an egg of Acartia sp. On the right a dinospore sticking to the egg surface. Fig. 2. As in Fig 1, $17 \mathrm{~min}$. later. Detached from the egg the trophont is swimming away. The dinospore has driven a peduncle into the egg interior. Fig. 3. Egg of Synchaete sp. infested with four dinospores, the right one already being a young trophont. Fig. 4. Trophont sucking on an egg of Synchaete sp. Figs 1-4: Scale bar $=50 \mu \mathrm{m}$ 

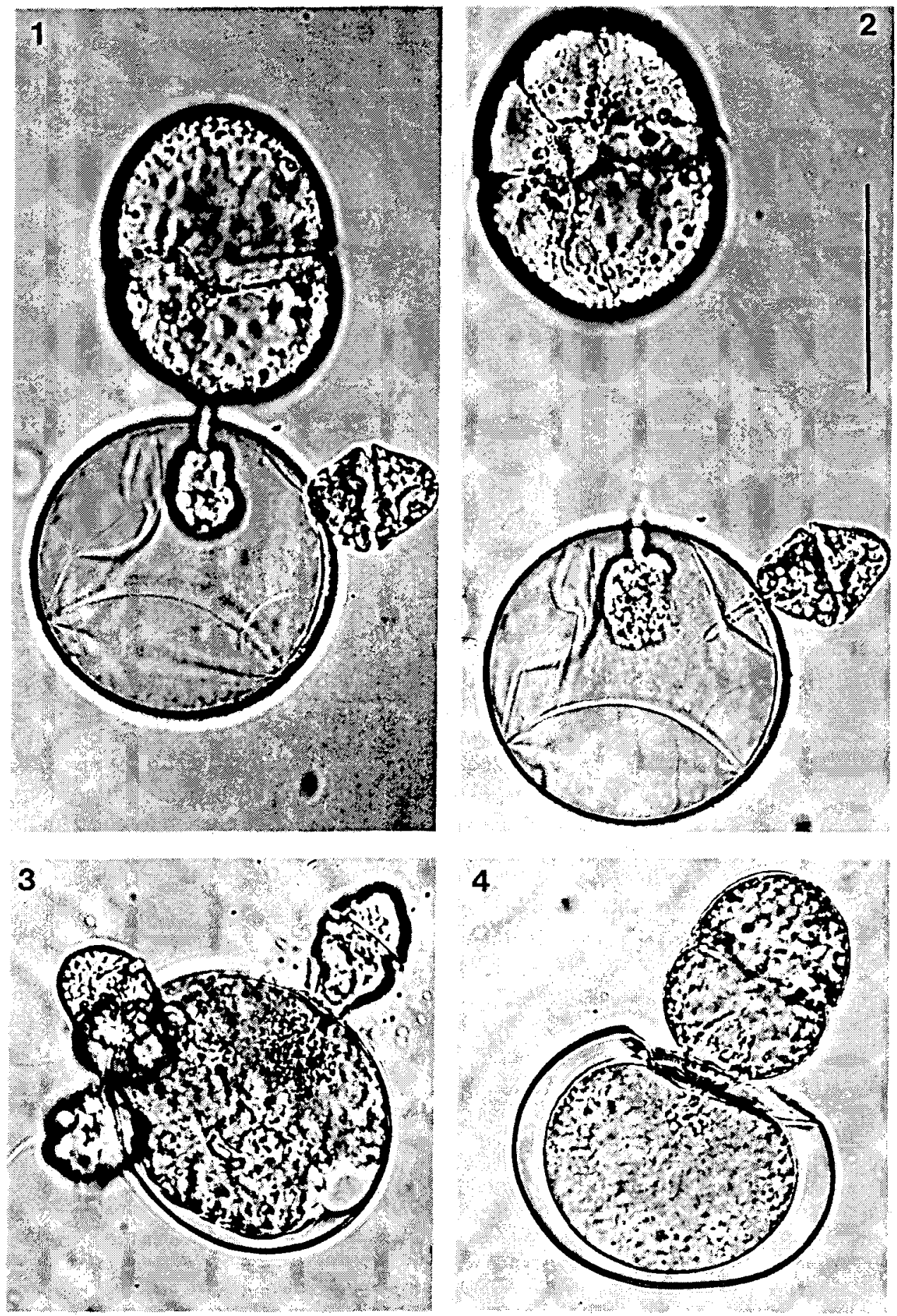
lying in the epicone. Trophont oval, slightly constricted by the girdle, up to $80 \mu \mathrm{m}$ in length. Tubiform peduncle with a wall, left inside the host after detachment of the parasite. Detached trophont initially motile, then by secretion of a gelatinous envelope developing into a palmelloid multiplication stage. By repeated binary fission up to 16 or 32 dinospores are formed. Type locality: German Bight near List/Sylt.

Latin diagnosis: Ectoparasitico ad ova copepodorum marinorum (Temora longicornis, Acartia, sp., Pseudocalanus elongatus) et rotaroriorum (Synchaete sp.). Dinosporae sine colore, longitudo 27-33 $\mu \mathrm{m}$, latitudo 22-27 $\mu \mathrm{m}$. Epiconus conicus, hypoconus hemisphaericus vel conicus. Cingulum medianum, sinistrorsum descendens, sulcus a antapice ad apicem extendens. Nucleus globosus ovo similis in epicono situs est. Trophontus ovo similis, cingulo leviter constrictus, longitudine usque ad $80 \mu \mathrm{m}$. Pedunculus tubiformis cum muro in hospite reliquitur post separationem parasitae. Trophontus separatus mobilis primo, deinde secretione involucrae mucoideae in stadio palmelloidio multiplicationis transformans. Dinosporae usque ad 16 vel 32 per bipartione repetita formantur.

Locus typicus: In mare sino germanico iuxta List/Sylt. Typus: Figurae 1-11.

The generic name and the epithet refer to the type locality.

\section{OBSERVATIONS}

As yet, Syltodinium listii has been found only sporadically in the North Sea plankton, during the summer months June-August. The species was recognized by its gelatinous palmelloid multiplication stages (Figs 7-9). The dinospores resulting from these stages are athecate, gymnodinoid, lacking chloroplasts, and have the roundish nucleus located in the epicone near the girdle region. In the middle, the cell body is conspicuously constricted by the girdle, which describes a left-handed spiral, displaced nearly its own width (Figs 10,11). The sulcus extends' to the epicone running there up to the apex as a narrow deeply incised furrow in a sigmoid curvature. On the hypocone, the sulcus flattens disappearing under a left ventral flap. The size data of the dinospores used for the diagnosis are derived from a few measurements, made either from infecting dinospores attached to the host, or from a 16-cell stage inside a gelatinous envelope. Occasionally, there are also dinospores only $22 \mu \mathrm{m}$ in length, possibly originating from a 32-cell stage.

Most probably chemotactically attracted, the dinospore attaches to the host by the posterior end of the hypocone (Fig. 1). Starting from the antapex a long tubiform peduncle is formed which penetrates the egg (Figs 2, 5). In cases of multi-infections dinospores often form a peduncle in vain, because other dinospores have already emptied the egg. Then, an unused peduncle tapers towards the front end and remains closed (Fig. 5). In contrast, a functioning peduncle appears enlarged the distal end, as can be observed in Figure 4. As only living specimens were examined, the mouth of the peduncle cannot be described in detail, since it is always masked by the food contents,

Figs. 5, 6. Syltodinium Listii. Fig. 5. Multi-infection on an egg of Acartia sp. Two mature trophonts, and four (two out of focus) dinospores trying to reach by their peduncles the rest of the host material. Fig. 6. Two trophonts feeding exceptionally (?) on a nauplius of Temora longicornis. Figs. 5, 6: Scale

$$
\text { bar }=50 \mu \mathrm{m}
$$



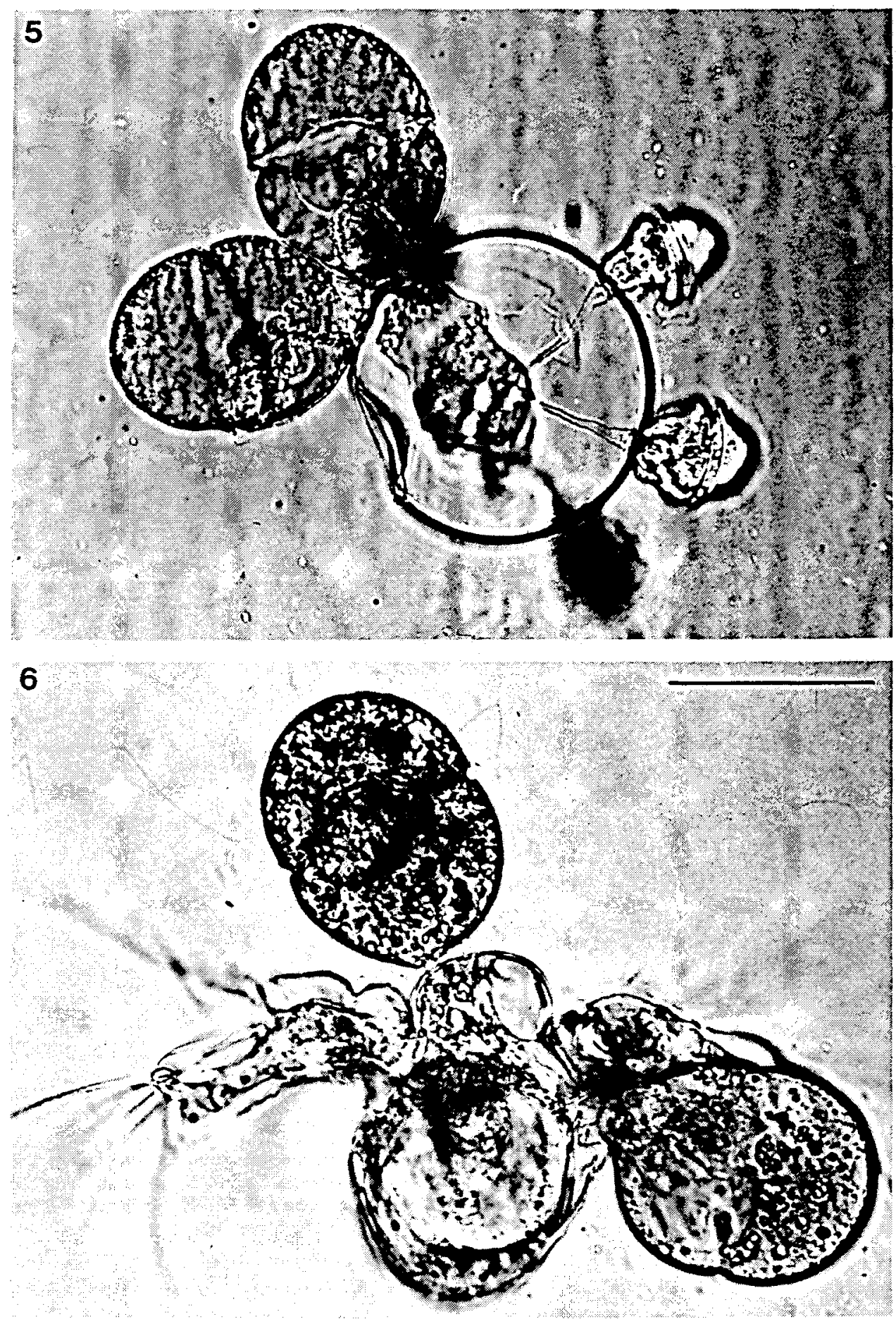



Figs. 7-10. Syltodinium listii. Fig. 7. Early multiplication stage inside a gelatinous envelope. Fig. 8. 8cell stage, surface of the gelatinous envelope crowded with bacteria. Fig. 9. 16-cell stage. Fig. 10. Liberated dinospore in oblique ventral view. Figs 7-9: Scale bar $=50 \mu \mathrm{m}$. Fig. 10: Scale bar $=20 \mu \mathrm{m}$ 
Fig. 11. Syltodinium listii.

Half-schematic drawing of a dinospore

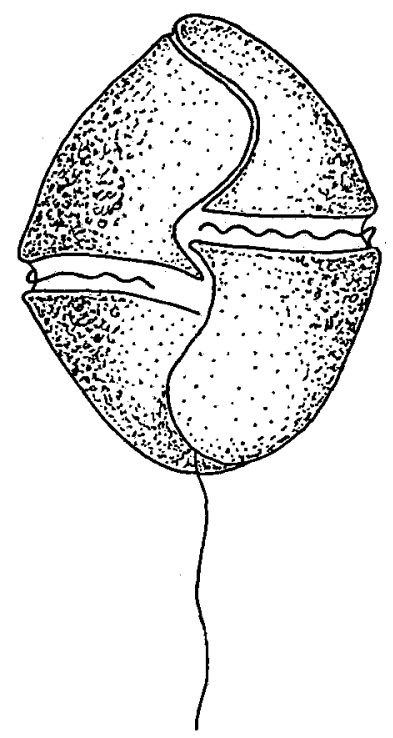

even after detachment of the host (Figs 1,2). The wall of the peduncle, presumably cellulosic, shows a cuff-like thickening in the region where it pierces the egg envelope.

Commencing food uptake through the peduncle, the dinospore transforms into a trophont. Increasing considerably in size the trophont elongates and assumes an oval shape (Figs 1, 2, 4-6). Thereby, girdle and sulcus become flattened. The time needed for food uptake may vary, depending on the amount of host material available. In general, the eggs are sucked out within ca $90 \mathrm{~min}$. The mature trophont detaches and becomes immediately motile by flagellar movement. The peduncle, or better its wall, is left behind inside the empty egg. The trophont swims around for a while, then settles down to the bottom of the Petri dish.

By secretion of mucilage the immobile stage becomes a palmelloid multiplication stage. Embedded in an amorphous nonlamellate gelatinous envelope, multiplication (sporogenesis) takes place by repeated binary fission resulting in colonies of up to 16 or 32 dinospores (Figs 7-9). In cultured material the outer surface of the gelatinous envelope is crowded with bacteria. In plankton samples additionally adhering detritus and other contaminants may fortify the envelope to a certain extent.

In the course of digestion of the food content, especially during the first cell divisions, the cells become densely crowded with highly light-refractive lipid granules (Figs 7, 8). Having gained a finite size the cluster of cells becomes motile, and the dinospores leave their slimy envelope. The whole multiplication phase takes about three days.

It is worth mentioning that the colonial cells retain their gymnodinoid outlines through all the developmental stages of sporogenesis (Figs 7-9). Although flagella are not obvious in these palmelloid stages, they are probably present in a functional condition to judge from the rapidity with which cells swim away after being artificially freed from the gelatinous matrix by a needle. But if done with early sporogenetic stages, e. g. in a 2-or 4-cell stage, prematurely liberated cells soon settle down and become a 
gelatinous "cyst" again. As the trophont also resembles an enlarged still functional dinospore, $S$. listii remains latently motile during the trophic and the sporogenetic phase as well.

Freshly released dinospores are capable of infecting eggs of copepods or rotifers within the same day. In the absence of hosts they remain motile for a few weeks and do not encyst. Two-week old dinospores can still infect freshly offered eggs.

Owing to the scarcity of the parasite in nature, the host range was obtained under laboratory conditions. The species was found feeding on eggs of the copepods Temora longicornis, Acartia sp., Pseudocalanus elongatus, and of the rotifer Synchaete sp. In one single case a nauplius of Temora was infected (Fig. 6); perhaps this was only possible under the limitations of a small Petri dish.

The short time of culturing $S$. listii did not allow extending the experiments on possible sexual reproduction. Further more, no resting stages have been observed as yet.

\section{DISCUSSION}

The ectoparasitic dinoflagellates Chytriodinium, Dissodinium, and the new genus Syltodinium have hosts in common: crustacean eggs, partly also eggs of rotifers. The host ranges of $D$. pseudolunula and $S$. listii even appear quite identical. Likewise, the dinospores of both species are of a similar gymnodinoid structure, but those of Syltodinium are on average a little larger and lack chloroplasts. However, beside other similarities, e. g. phagotrophic feeding by a peduncle, Syltodinium has its own characteristics. Thus, after the trophic phase palintomic multiplication takes place in a palmelloid stage embedded in a gelatinous envelope. I refrain from designating this stage a "gelatinous cyst" ("Gallertcyste": Lindemann, 1928), since the cells retain their monadoid shape and remain latently motile during the multiplication phase. The monadoid state of $S$. listii is apparent during the whole vegetative life cycle. This is in contrast to Dissodinium, where the monadoid state is restricted to the dinospores (Elbrächter \& Drebes, 1978). Additionally, in Dissodinium sporogenesis takes place inside two successive cyst stages, termed primary and secondary cysts.

Though sharing a similar host substrate (crustacean eggs), Syltodinium is clearly distinguished from Chytriodinium. The three members of Chytriodinium are described as feeding osmotrophically on eggs of Euphausiacea, and sporogenesis has already started while still attached to the host and before food uptake has finished (Cachon \& Cachon, $1968,1987)$. That means, there is no separation between the parasitic stage attached to the host and the sporogenetic stage free floating in the plankton, as known in Dissodinium and Syltodinium.

With regard to the taxonomic rank of Syltodinium among the parasitic dinoflagellates, this is, as yet, uncertain.

Acknowledgements. I am grateful to Mrs. H. Halliger for technical assistance. Mr. J. Frank (List) kindly corrected the Latin diagnoses. 


\section{LITERATURE CITED}

Cachon, J. \& Cachon, M., 1968. Cytologie et cycle évolutif des Chytriodinium. - Protistologica 4, 249-262.

Cachon, J. \& Cachon, M., 1987. Parasitic dinoflagellates. In: The biology of dinoflagellates. Ed. by F. J. R. Taylor. Blackwell, Oxford, 785 pp. (Botanical Monographs. 21).

Chatton, E., 1912. Diagnoses préliminaires de Péridiniens parasites nouveaux. - Bull. Soc. zool. Fr. $37,85-93$.

Dogiel, V., 1906. Beiträge zur Kenntnis der Peridineen. - Mitt. zool. Stn Neapel 18 (1), 1-45.

Drebes, G., 1969. Dissodinium pseudocalani sp. nov., ein parasitischer Dinoflagellat auf Copepodeneiern. - Helgoländer wiss. Meeresunters. 19, 58-67.

Drebes, G., 1978. Dissodinium pseudolunula (Dinophyta), a parasite on copepod eggs. - Br. phycol. J. 13, 319-327.

Drebes, G., 1981. Possible resting spores of Dissodinium pseudolunula (Dinophyta) and their relation to other taxa. - Br. phycol. J. 16, 207-215.

Drebes, G., 1984. Life cycle and host specificity of marine parasitic dinophytes. - Helgoländer Meeresunters. 37, 603-622.

Elbrächter, M. \& Drebes, G., 1978. Life cycles, phylogeny and taxonomy of Dissodinium and Pyrocystis (Dinophyta). - Helgoländer wiss. Meeresunters. 31, 347-366.

Gönnert, R., 1936. Sporodinium pseudocalani n. g., n. sp., ein Parasit auf Copepodeneiern. - Z. ParasitKde 9, 140-143.

John, A. W. G. \& Reid, P. C., 1983. Possible resting cysts of Dissodinium pseudolunula Swift ex Elbrächter et Drebes in the Northeast Atlantic and the North Sea. - Br. phycol. J. 18, 61-67.

Lindemann, E., 1928. Abteilung Peridineae (Dinoflagellatae). In: Die natürlichen Pflanzenfamilien. Hrsg. von A. Engler. Engelmann, Leipzig, 2, 1-345.

McLachlan, J., 1973. Growth media - marine. In: Handbook of phycological methods. Culture methods and growth measurements. Ed. by J. R. Stein. Cambridge Univ. Press, Cambridge, $448 \mathrm{pp}$. 